\title{
Anterolateral Thigh Flap-the Optimal Flap in Coverage of Severe Elbow Injuries
}

\author{
Venkata Koteswara Rao Rayidi ${ }^{1}$ \\ Karavattula Swathi ${ }^{1}$ \\ ${ }^{1}$ Department of Plastic Surgery, Nizams Institute of Medical \\ Sciences, Hyderabad, India \\ ${ }^{2}$ Department of Plastic Surgery, Care Hospitals, Hyderabad, India \\ Indian J Plast Surg 2019;52:314-321
}

\begin{abstract}
Address for correspondence Prakash Panagatla, MS, MCh, Department of Plastic Surgery, Nizams Institute of Medical Sciences, Hyderabad 500082, India (e-mail: drprakashcool@gmail.com).
\end{abstract}

\begin{abstract}
Keywords

- anterolateral thigh flap

- elbow injuries

- acute trauma

Introduction Traditionally, the latissimus dorsi muscle with or without skin paddle has been the flap of choice for coverage of elbow defects. The ALT flap has found application in elective upper limb defects on account of it's ability to be tailor made for individual defects. Our series of 10 cases shows the advantages of using this flap for acute trauma defects.

Materials and Methods Consecutive 10 cases of severe elbow injuries, involving varying amounts of the lower arm and proximal forearm underwent debridement followed by coverage using the free anterolateral thigh flap. Nine of 10 arterial anastomosis were done end to side to the brachial artery and venous anastomosis to the veins accompanying the artery. Seven of these patients had long bone fractures and elbow dislocations, stabilised using external fixator. Four patients needed primary muscle or tendon repair and nerve repair or graft.

Results There was 1 total flap loss, intraoperatively where a TFL flap had been used in a 71 year-old patient. Nine of 10 had successful wound coverage. Using Jupiter criteria, 2 had excellent, 3 had good, 3 had fair, and 1 had poor outcome.

Conclusion This consecutive series of moderate and severe elbow injuries demonstrates that the ALT flap should be considered as the flap of first choice, specifically when there is a need.
\end{abstract}

\section{Introduction}

Severe elbow injuries result in large wounds leading to exposure of vital structures like vessels, nerves, tendons, and bone. There may be disruption of the skeleton of the arm and/or forearm with varying degrees of injury to the muscles, nerves, and even vessels - the last one leading to compromise in distal vascularity. Timely and appropriate soft tissue coverage is helpful in optimal functional recovery. ${ }^{1}$

Though anatomically the elbow is the area of the cubital fossa, severe injuries do cause varying amounts of skin loss in the distal arm and proximal forearm.

Soft tissue coverage around elbow has been traditionally done using numerous local and pedicled regional flaps like the radial forearm, flexor carpi ulnaris muscle, reverse

received

July 9, 2019

accepted after revision

October 15, 2019

published online

December 30, 2019 lateral arm, brachioradialis, anconeus, and thoracoabdominal flaps. ${ }^{2,3}$ When the loss of skin cover has been to such a degree that it precludes the use of local flaps, the thoracoabdominal flap can provide reliable coverage for moderate defects either anterior or posterior based. ${ }^{4}$

For large defects at the "elbow," the latissimus dorsi has been the "workhorse" flap for coverage; pedicle flap transfer is followed by split skin grafting to achieve wound closure. Even though this can avoid a microvascular procedure, the disadvantages include the inability to get a stable skin cover in the entire wound for any future reconstructive needs, the loss of a potential functioning muscle that can later be used for restoration of elbow flexion if needed, and questionable survival of the distal reaches of the flap in defects much lower than the cubital fossa. ${ }^{5}$
License terms

(요 (1) $\Theta \circledast$ 
The anterolateral thigh (ALT) flap addresses these shortcomings of the latissimus dorsi flap by providing stable supple skin over the entire wound even as far as the mid-forearm, permitting reliable primary or secondary reconstruction of lost muscles and nerves. In the event of distal critical ischemia, vascular restoration can also be incorporated into the treatment plan with little difficulty.

\section{Materials and Methods}

Ten consecutive cases of acute traumatic elbow injuries underwent free ALT flap cover between April 2014 and June 2018. Seven cases were due to motor vehicle accident (MVA), two were machine inflicted injuries, and one had a fall of a very heavy object. There were eight males and two females. The ages ranged from 14 to 71 years.

Four of the 10 patients were operated within 48 hours of trauma and 6 between 2 and 7 days, following primary management at another hospital. All except three patients in the delayed referral group had debridement and flap cover simultaneously.

Five had concomitant humeral shaft and/or forearm fractures and three had compound elbow dislocations that were stabilized using external fixator. Two patients had only soft tissue injuries and hence were managed with external removable splint after flap transfer.

Four of the 10 injuries needed reconstruction of muscle and/or nerve injuries and one patient needed a vein graft to restore brachial artery continuity ( - Table $\mathbf{1}$ ).
Nine of the 10 arterial anastomoses were done end to side to the brachial artery in the middle or lower third of the arm and one end to end to the radial artery. In one case, a reversed interposition vein graft was done to reconstitute the thrombosed brachial artery. The flap, in this case, was then hooked end to side to the brachial artery, proximal to this anastomosis ( Fig. 1A-D).

\section{Results}

Among the 10 cases, 6 ALT flaps, 1 tensor fascia lata (TFL) flap, and 2 composite ALT and rectus femoris flaps were used (TFL flap was chosen due to absence of suitable perforators following exploration of the thigh). Flap size ranged from 120 to $540 \mathrm{~cm}^{2}$, the mean flap size being $255 \mathrm{~cm}^{2}$.

Nine of the 10 flaps survived. There was one re-exploration for drainage of hematoma near the anastomotic site after 72 hours. The only complete flap loss happened due to arterial failure, twice on-table, due to atherosclerosis in the recipient brachial artery and small diameter of the primary pedicle of the TFL flap.

There was no skin flap discoloration in any of the ALT flaps. Delayed loss of rectus muscle-in a composite ALT rectus femoris flap, where it had been used in extending the area of coverage-occurred on account of infection; it had to be removed but with no compromise of the ALT skin. This area in the dorsal forearm was allowed to granulate for skin grafting leading to a loss of hand extensor function (Case 10).

Table 1 Patient details pertaining to extent of injury

\begin{tabular}{|c|c|c|c|c|c|c|}
\hline & Cause & Bone injury & Arterial injury & $\begin{array}{l}\text { Muscle and tendon } \\
\text { injury }\end{array}$ & Nerve injury & Time to surgery \\
\hline 1 & MVA & $\begin{array}{l}\text { Humeral shaft distal } \\
\text { third }\end{array}$ & & - & - & $<48 \mathrm{~h}$ \\
\hline 2 & MVA & $\begin{array}{l}\text { Soft tissue injury } \\
\text { only }\end{array}$ & & Cut biceps/brachialis & Median nerve & $7 d$ \\
\hline 3 & $\begin{array}{l}\text { Fall of heavy } \\
\text { weight }\end{array}$ & $\begin{array}{l}\text { Humerus distal } \\
\text { third and proximal } \\
\text { forearm }\end{array}$ & & $\begin{array}{l}\text { Crushed common flexor } \\
\text { origin }\end{array}$ & - & $3 d$ \\
\hline 4 & MVA & $\begin{array}{l}\text { Forearm both bone } \\
\text { fracture upper third }\end{array}$ & & $\begin{array}{l}\text { Crushed wrist flexors, wrist } \\
\text { extensor, and brachiora- } \\
\text { dialis }\end{array}$ & Median nerve & $<48 \mathrm{~h}$ \\
\hline 5 & MVA & Elbow dislocation & & - & - & \\
\hline 6 & MVA & $\begin{array}{l}\text { Soft tissue injury } \\
\text { only }\end{array}$ & $\begin{array}{l}\text { Thrombosed bra- } \\
\text { chial artery }\end{array}$ & Cut pronator teres & - & $<48 \mathrm{~h}$ \\
\hline 7 & Machinery & $\begin{array}{l}\text { Soft tissue injury } \\
\text { only }\end{array}$ & & $\begin{array}{l}\text { Partial cut biceps and bra- } \\
\text { chialis, cut pronator teres } \\
\text { and brachioradialis }\end{array}$ & - & $5 d$ \\
\hline 8 & MVA & Elbow dislocation & & $\begin{array}{l}\text { Injury to wrist extensor, bra- } \\
\text { chioradialis, and pronator } \\
\text { teres }\end{array}$ & $\begin{array}{l}\text { Superficial radial } \\
\text { nerve }\end{array}$ & $3 d$ \\
\hline 9 & Machinery & $\begin{array}{l}\text { Soft tissue injury } \\
\text { only }\end{array}$ & $\begin{array}{l}\text { Radial artery } \\
\text { thrombosis }\end{array}$ & $\begin{array}{l}\text { Crushed wrist and superfi- } \\
\text { cial finger flexors }\end{array}$ & - & $<48 \mathrm{~h}$ \\
\hline 10 & MVA & $\begin{array}{l}\text { Forearm both bone } \\
\text { fracture upper third }\end{array}$ & & - & - & $3 d$ \\
\hline
\end{tabular}

Abbreviation: MVA, motor vehicle accident. 

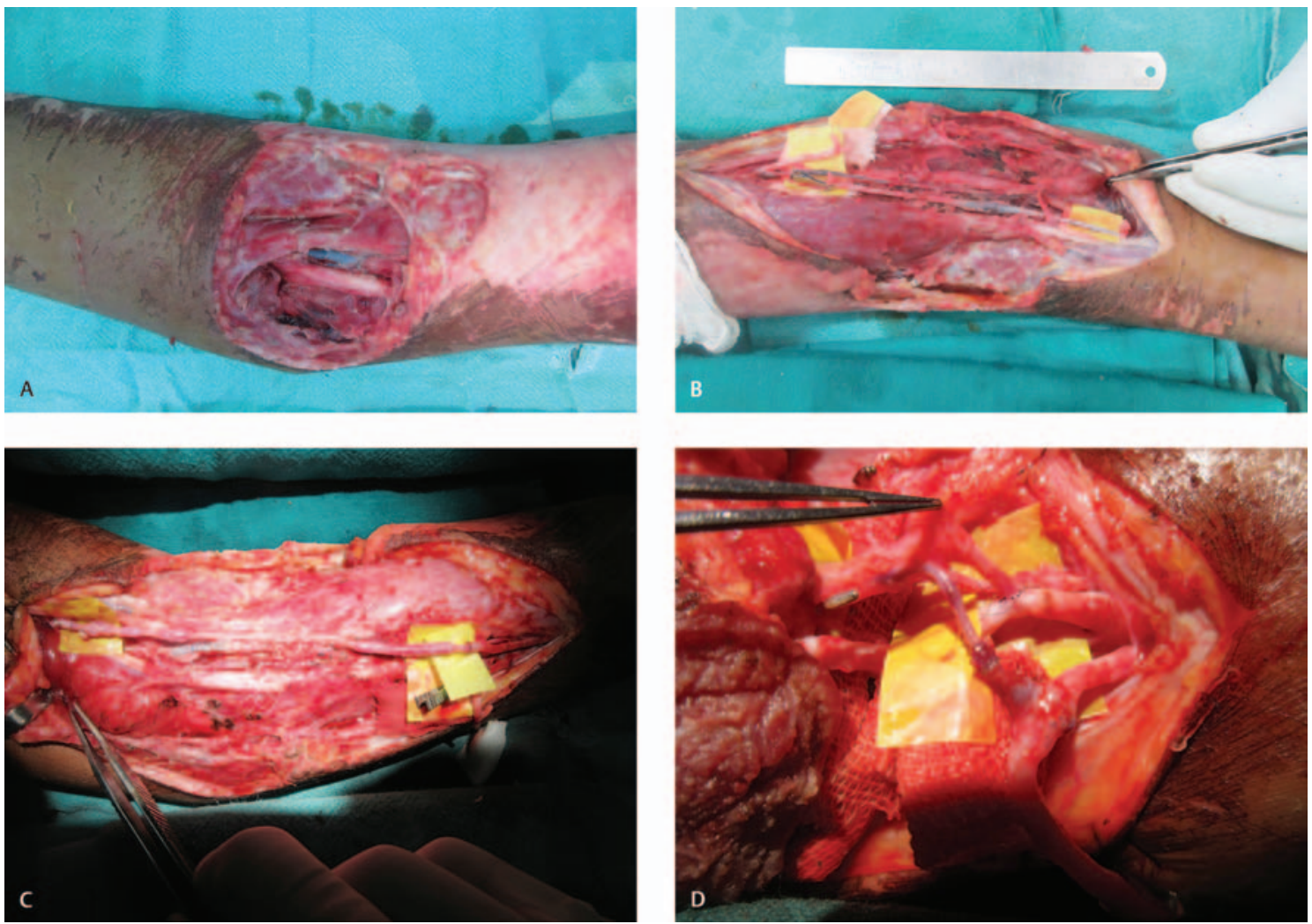

Fig. 1 (A) Crush injury of right elbow with abrasions on distal arm. (B) Debrided wound with thrombosed brachial artery. (C) Reversed vein graft for defect in brachial artery. (D) End to side anastomosis of anterolateral thigh flap above the proximal end of vein graft.

Table 2 Patient details pertaining to procedure details of components

\begin{tabular}{|l|l|l|l|l|l|l|l|}
\hline & $\begin{array}{l}\text { Defect } \\
\text { size } \\
(\mathbf{c m})\end{array}$ & Flap type & $\begin{array}{l}\text { No. } \\
\text { of } \\
\text { veins }\end{array}$ & Reconstruction & $\begin{array}{l}\text { Flap size } \\
\text { (cm) }\end{array}$ & $\begin{array}{l}\text { Extent of } \\
\text { flap beyond } \\
\text { olecranon (cm) }\end{array}$ & $\begin{array}{l}\text { Degree } \\
\text { of wound } \\
\text { coverage }\end{array}$ \\
\hline 1 & & Musculocutaneous ALT & 2 & - & $12 \times 10$ & 15 & Critical area \\
\hline 2 & & Septocutaneous ALT & 1 & $\begin{array}{l}\text { Cable graft median nerve, biceps } \\
\text { repair }\end{array}$ & $18 \times 10$ & 12 & Critical area \\
\hline 3 & & Musculocutaneous ALT & 2 & - & $20 \times 18$ & 6 & Critical area \\
\hline 4 & & $\begin{array}{l}\text { ALT and functioning } \\
\text { rectus femoris }\end{array}$ & 2 & $\begin{array}{l}\text { Direct repair median nerve, func- } \\
\text { tioning rectus muscle for FDP using } \\
\text { nerve to pronator teres }\end{array}$ & $30 \times 18$ & 19 & Complete area \\
\hline 5 & & $\begin{array}{l}\text { TFL musculocutaneous } \\
\text { flap }\end{array}$ & 2 & - & $12 \times 10$ & - & Complete area \\
\hline 6 & & & 2 & $\begin{array}{l}\text { Reversed vein graft from brachial to } \\
\text { radial artery }\end{array}$ & $18 \times 10$ & 8 & Complete area \\
\hline 7 & & Musculocutaneous ALT & 2 & Biceps tendon repair with fascia lata & $18 \times 12$ & 10 & Complete area \\
\hline 8 & & Musculocutaneous ALT & 1 & Wrist extensor muscle repair & $18 \times 12$ & 12 & Critical area \\
\hline 9 & & Septocutaneous ALT & 1 & - & $-15 \times 12$ & 8 & Complete area \\
\hline 10 & & $\begin{array}{l}\text { ALT and rectus femoris } \\
\text { (coverage) }\end{array}$ & 2 & - & $34 \times 13$ & 17 & Complete area \\
\hline
\end{tabular}

Abbreviations: ALT, anterolateral thigh; FDP, flexor digitorum profundus; TFL, tensor fascia lata.

an account of absence of suitable ALT perforator, the TFL was chosen as donor flap; a very short pedicle, small diameter of vessel, and atherosclerosis in the brachial artery led to intraoperative arterial failure on table. On account of the patient being 70 years old, further free flap for salvage was deemed inappropriate. The wound was treated with dressings and negative pressure wound therapy followed by split skin grafting. Follow-up revealed a fixed elbow flexion contracture of 70 degrees, with no compromise in hand function.

bLoss of rectus component of the flap occurred gradually from the 5th day. This was due to infection on account of incomplete debridement on the dorsum of the forearm; there was no compromise in vascularity of the ALT skin component. Debridement was followed by dressings and split skin grafting leading to a long-term loss in hand extensor function. 
In five of the nine successful transfers, the flap was used for complete wound coverage; in rest of the four, the flap coverage was given to the critical portion of the defect ( - Table 2 ).

All patients needed split skin grafting at the donor site; all except two donor sites healed primarily and these two needed secondary skin grafting.
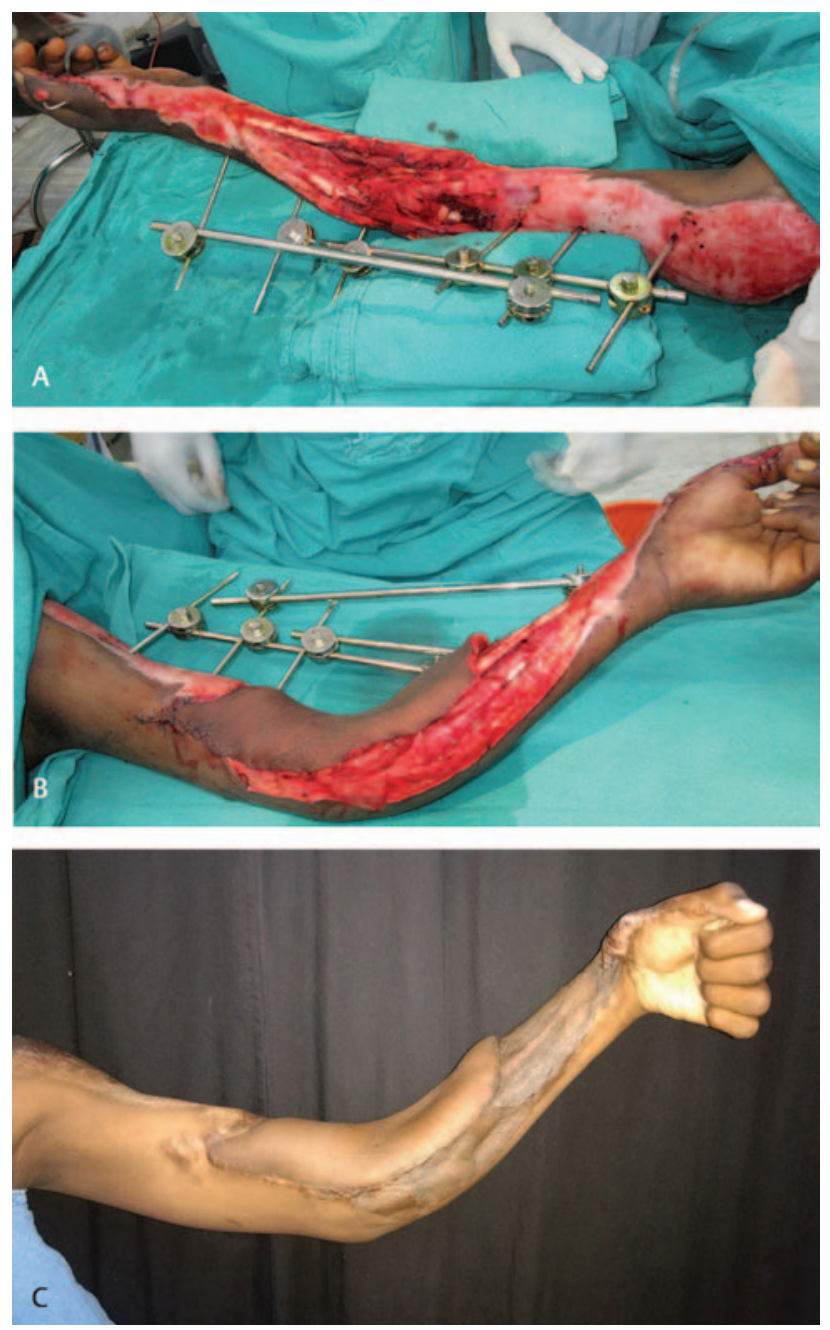

Fig. 2 (A) Debrided elbow wound extending to the forearm. (B) Anterolateral thigh flap coverage over elbow, proximal forearm, and distal arm: medial view. (C) Settled flap, good hand function, but with poor elbow movement.
Duration of follow-up extended from 7 to 32 months.

The only complete flap loss needed negative pressure wound therapy followed by split skin grafting leading to a healed wound. This resulted in a fixed elbow flexion contracture of 70 degrees but with no compromise in hand function.

One patient had a humeroulnar ankylosis leading to a fixed elbow at 30 degrees from the neutral and one had a nonunion of forearm fractures, which were subsequently plated successfully ( - Fig. 2 A-C).

Both the patients with repair of biceps brachii achieved complete active range of motion at follow-up. Recovery in the median nerve territory was $\mathrm{S} 2+$ in the case with nerve grafts and S3 in the case with direct repair. Neither case had recovery of intrinsic muscles. In addition, the patient in whom nerve grafts had been used needed tendon transfer to augment finger flexor function ( - Table 3 ).

The rectus femoris was used as a functioning muscle transfer for flexor digitorum profundus function with the nerve to the brachialis as the motor nerve. At 10-month follow-up, finger flexion was demonstrated with an active range of 100 out of a possible 270 degree range (Case 4).

None of the flaps were primarily thinned. On account of functional nature of the reconstruction, only two of the nine patients expressed concern regarding the flap bulk at the recipient site, one of whom had undergone secondary flap thinning.

Follow-up evaluation in nine patients with successful flap transfer and complete wound healing was done using Jupiter criteria for assessment of elbow function ( - Table 4 ).

Jupiter criteria evaluate pain, disability, and range of movement. Symptoms are recorded at clinical interview; elbow and forearm movements are measured using a goniometer, recording the extension of the elbow with the forearm in maximal supination. The normal side was used in

Table 4 Outcome based on the Jupiter criteria

\begin{tabular}{|l|l|l|}
\hline & $\begin{array}{l}\text { With skeletal } \\
\text { injuries }\end{array}$ & $\begin{array}{l}\text { Without skeletal } \\
\text { injuries }\end{array}$ \\
\hline Excellent & - & 2 \\
\hline Good & 2 & 1 \\
\hline Fair & 3 & - \\
\hline Poor & 1 & - \\
\hline
\end{tabular}

Table 3 Details of specific reconstruction of nerve and muscle tendon injury

\begin{tabular}{|l|l|l|l|l|}
\hline & Vascular repair & Biceps repair & $\begin{array}{l}\text { Muscle/tendon repair } \\
\text { in forearm }\end{array}$ & Nerve repair \\
\hline Case 2 & - & $\begin{array}{l}\text { Direct repair with 2 “0” polypropylene, } \\
\text { reinforced with fascia lata graft }\end{array}$ & - & $\begin{array}{l}8 \mathrm{~cm} \text { sural nerve graft for } \\
\text { median nerve } 4 \text { cables } \\
\text { across the elbow }\end{array}$ \\
\hline Case 4 & - & - & - & $\begin{array}{l}\text { Direct repair of median } \\
\text { nerve in lower third arm }\end{array}$ \\
\hline Case 6 & $\begin{array}{l}7 \mathrm{~cm} \text { reversed vein } \\
\text { graft from brachial to } \\
\text { radial artery }\end{array}$ & - & - & - \\
\hline Case 7 & - & $\begin{array}{l}\text { Direct repair with 2 “0” polypropylene, } \\
\text { reinforced with fascia lata graft }\end{array}$ & - & - \\
\hline Case 8 & - & - & Repair of wrist extensors & - \\
\hline
\end{tabular}

Note: Case 4 had a composite anterolateral thigh and functioning rectus femoris flap for replacing lost function in finger flexors, using the motor nerve branch to the brachialis in the distal third of the arm. 
comparison. Historically, this scale has been used to assess the effect of replacement arthroplasty in arthritis, but on account of its semi-objective and patient-input nature we have assessed our results using this scale. ${ }^{6}$

\section{Discussion}

Even as early as the late 1980s and the 1990s, free flaps were described for coverage of upper extremity wounds following trauma. A reliance was made on local and regional flaps for coverage issues in the proximal portions of the upper limb, specifically the elbow.7,8

Hallock used five local fascial flaps and three free flaps for elbow coverage in his series of upper extremity trauma. He advocated using local flaps for mild injuries but maintained that free flaps were necessary in larger or composite defects. ${ }^{9}$

Over the years, the pedicled latissimus dorsi became the standard flap for coverage of elbow defects on account of its reliable vascular pedicle, proximity to the defect location, and minimal donor morbidity following harvest.

Harvey et $\mathrm{al}^{10}$ used six pedicled latissimus dorsi muscles with skin paddle based on the anterior half of the muscle to cover three defects around the elbow, none of which were more than $3 \mathrm{~cm}$ from the olecranon; there was no muscle necrosis and the authors ascribe the success to "not tunneling" the carrier portion of the muscle and in taking care "not to design" the skin paddle in the distal-most portion of the muscle. This necessarily restricts the reach of the flap.

Ma et al in a series of 20 patients had no flap necrosis and complete healing following pedicled latissimus dorsi flap transfer; 15 of these had associated fractures fixed internally or with external fixator and 5 followed necrotizing infection. The authors do not mention defect size or location in objective terms but case illustrations show that most were in the peri-olecranon area and at least in one case the defect extended to the mid-forearm. Extrapolating their function outcome to the Jupiter criteria, there were 15 excellent, 3 fair, and 1 poor result. ${ }^{11}$

Hacquebord et al in a retrospective study of 18 patients mainly following trauma covered an average defect size of $420 \mathrm{~cm}^{2}$ using the pedicled latissimus dorsi flap with distal flap necrosis partial in 3 and total in 1.

Three of these four cases had a change in plan with conversion of one pedicled to free latissimus dorsi flap, and two needed a secondary fasciocutaneous flap for defect salvage. All these three had varying amount of defect extension to the proximal third of the forearm. ${ }^{12}$

There is a variation in the degree to which the pedicled flap can reach beyond the elbow; some authors report as $3 \mathrm{~cm}$ and others as $8 \mathrm{~cm} \cdot{ }^{13}$

A cadaver dissection of the latissimus dorsi muscle was performed by Jutte et al. ${ }^{14}$ When transposed through an anterior plane, the muscle was able to reach $8.4 \mathrm{~cm}(2-18 \mathrm{~cm}$ range) distal to the olecranon compared with $6.5 \mathrm{~cm}$ (0-15 cm range) when transposed through a posterior plane.
All cadaver dissections demonstrated that the muscle was reliably able to reach the olecranon and beyond in both anterior and posterior aspects of the arm.

In 2003, more than 150 free flaps for upper limb defects had been reported; the majority $85 \%$ involved the distal forearm and hand but $7 \%$ were for defects of the elbow. No less than 10 different flaps were used but not the ALT, and the failure rate was around $9 \% .{ }^{15}$

The morbidity of the latissimus dorsi flap can be offset by choosing a microvascular flap especially in severe elbow injuries. The problem of recipient vessels in the distal arm can be circumvented by opting for an end to side arterial anastomosis to the large caliber brachial artery.

The earliest description of perforator-based free flaps in the upper limb defects was by Chen et al, ${ }^{16}$ where 9 of 36 patients had such free flaps for acute upper limb defects; the majority had ALT flaps. At least two of these were for coverage of proximal forearm and the contiguous cubital fossa area. The authors further stated that this flap affords skin-to-skin healing and facilitates secondary surgery of the elbow; further, the vascularized vastus lateralis muscle that can be used to obliterate dead space and access to fascia lata grafts are available for bridging tendon defects primarily.

Wang et al reported 15 patients who needed ALT flap for upper limb defects; 13 were for traumatic wounds-3 of these were located in the proximal forearm or distal arm. There was one total and two partial flap necroses. ${ }^{17}$

There is little published data on the application of the ALT flap to elbow coverage. The detailed study of Choudry et $\mathrm{al}^{18}$ showed excellent results by using the ALT free flap for reconstruction in injuries to the upper extremity. This study highlights the problems of pedicled latissimus dorsi flap when used for coverage of defects well distal to the olecranon.

Choudry et $\mathrm{al}^{18}$ reported using free tissue transfers in only $19 \%$ of cases in their series of 96 patients requiring soft tissue coverage of the elbow. Of the 19 free flaps, only 5 (26\%) were ALT flaps, with the latissimus dorsi being the flap of choice ( $42 \%)$.
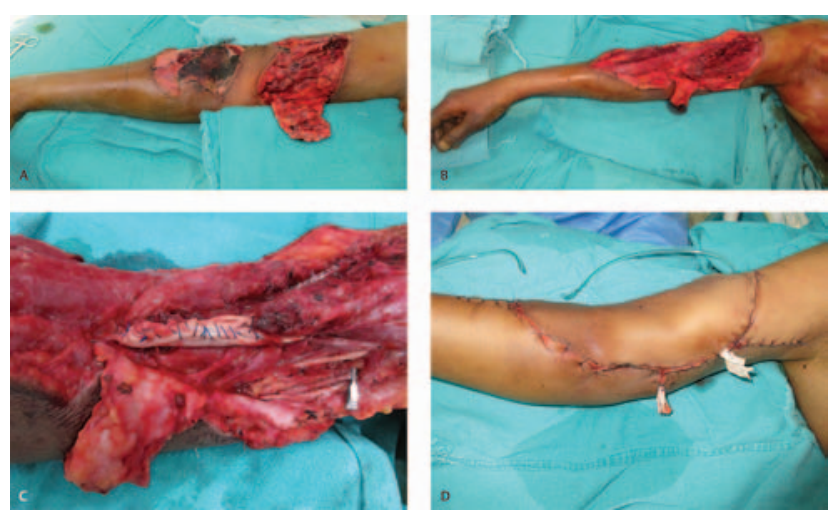

Fig. 3 (A) Elbow skin loss with avulsion of distal arm skin. (B) Debrided wound with partial loss of biceps, brachialis muscles. (C) Fascia lata graft to reinforce repaired biceps tendon. (D) Anterolateral thigh flap transfer completed. 

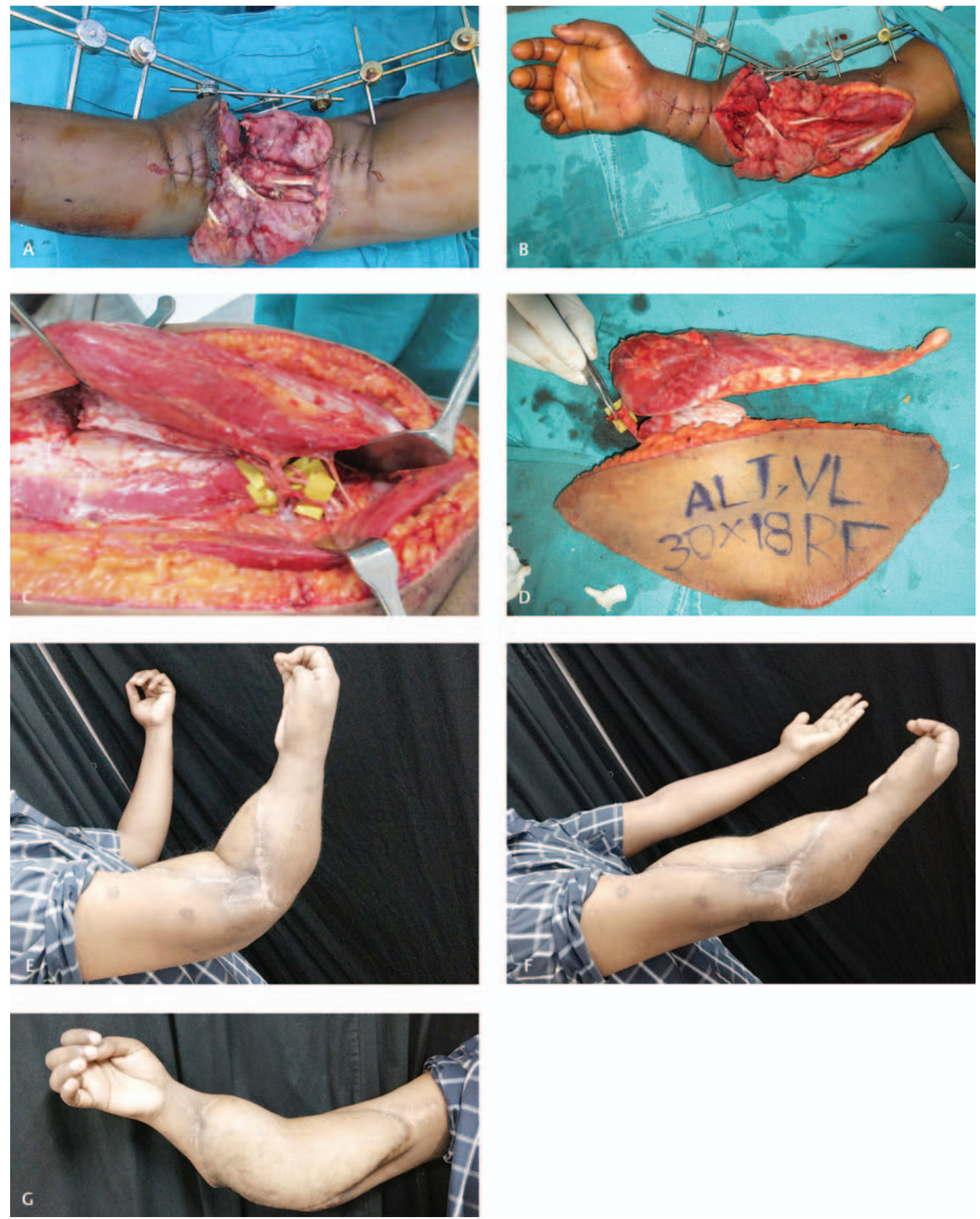

Fig. 4 (A) Wound over the right elbow with fracture in both forearm bones, referred after fixation. (B) Completion of debridement, loss of finger flexor muscles, and median nerve. (C) Composite flap of anterolateral thigh (ALT) and rectus femoris dissection completed. (D) Composite flap of ALT with vastus lateralis cuff and rectus femoris on a common pedicle. (E) Active range of motion (AROM) of the elbow joint: fair result. (F) AROM of the elbow joint: fair result. (G) Finger flexion by reinnervated rectus femoris muscle.

All total flap failures occurred in pedicled flaps. Significant distal necrosis occurred in $14 \%$ of pedicled latissimus dorsi muscle flaps; in all cases, these muscles were used to cover wounds that extended beyond the olecranon and over the proximal ulna. There were 10 secondary flaps performed for partial or total flap failures. Fifty percent of the salvage procedures were performed on pedicled latissimus dorsi flaps. It certainly would be ideal in injuries of the proximal arm extending to the elbow, especially when reliable recipient vessels are lacking.

Outcome analysis revealed that defects smaller than $40 \mathrm{~cm}^{2}$ were associated with better postoperative motion, averaging 105 degrees compared with defects greater than $40 \mathrm{~cm}^{2}$ with which patients averaged 80 degrees of postoperative motion. 
Eight of the 10 flaps in our series survived completely to result in primary healing; the functional result was excellent and good in four cases without any skeletal injuries. In the presence of skeletal injury, only one had a good, three had a fair, and one had a poor result.

The most proximal location of the defect beyond the elbow was $6 \mathrm{~cm}$ and the most distal location beyond the elbow was $19 \mathrm{~cm}$ (-Fig. 3A-D).

Even though the length of the latissimus dorsi muscle would be longer, the proximal-most pivot point-when the free ALT flap is used-is shifted far distally to the junction of the middle and lower third of the arm, permitting adequate coverage in extensive injuries (-Fig. 4A-G).

A smaller series was reported recently, specifically using free flaps for injuries of the elbow, by Chui et al for defects ranging from 3 to $450 \mathrm{~cm}^{2} .{ }^{19}$ Three of the five patients with documented traumatic defects around the elbow underwent skeletal stabilization with or without concomitant nerve reconstruction prior to a free ALT flap anastomosed end to side to the brachial artery. The authors had no flap losses and
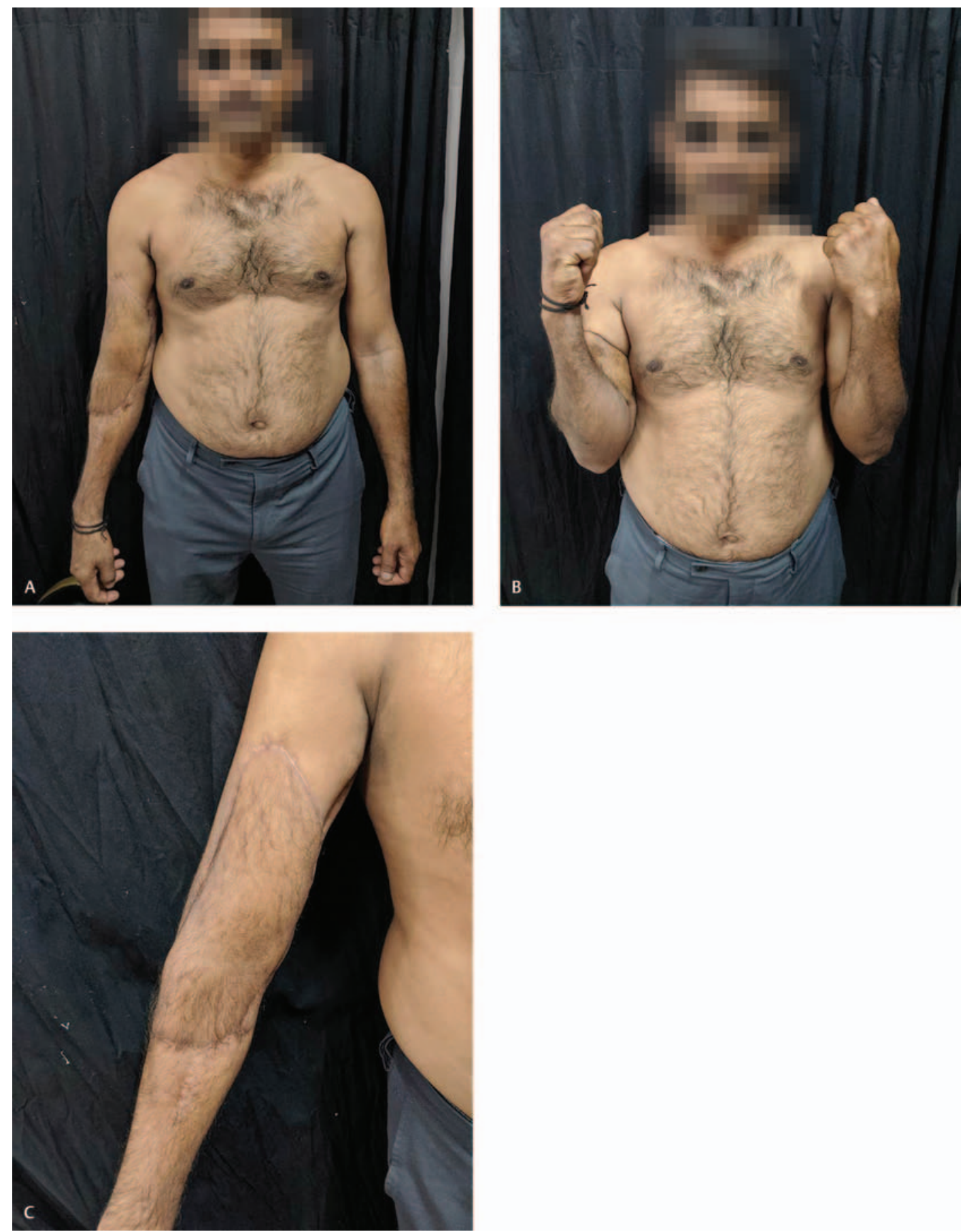

Fig. 5 (A) Active range of motion (AROM) of the elbow joint: excellent result. (B) AROM of the elbow joint: excellent result. (C) Settled anterolateral thigh flap after 8 months. 
a range of elbow flexion 45 to 140 degrees at follow-up. This outcome analysis was based on the work of Morrey et al who specified that a residual 100 degrees of elbow flexion was commensurate with activities of daily living. ${ }^{20}$

In a series of 32 patients with ALT flap coverage for mixed indications, 2 of the 32 patients had forearm and elbow defects; the authors had also occasion to use the flap as a flow-through flap for restitution of distal vascularity. Partial flap loss happened in five cases in all and total flap loss in two trauma defects that even led to amputation. Since the case load contained tumor and infection as the leading etiology, the authors quote a limb salvage rate of $94 \%$ and an overall complication rate of more than $30 \%$ including flap necrosis and infections. ${ }^{21}$

Since large defects following trauma can cause compromise of function on account of injury to vital nerves and muscles, the ALT flap emerges as the flap of choice permitting stable skin cover and functional reconstruction. Familiarity with an end to side arterial anastomosis ensures distal migration of the flap pivot point (as against the pedicled latissimus dorsi flap) and reliable coverage of large elbow

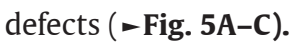

\section{Conclusion}

Extensive elbow injuries involving the proximal and mid-forearm are more reliably covered by using the ALT flap, with an end to side anastomosis to the brachial artery at the mid- or lower arm. It further ensures stable skin coverage and graft, thus permitting further reconstructions as necessary. This also spares the latissimus dorsi for a pedicled functional muscle transfer for future elbow flexion if needed.

\section{Conflict of Interest}

None declared.

\section{References}

1 Kelley BP, Chung KC. Soft tissue coverage for elbow trauma. Hand Clin 2015;31(4):693-703

2 Stevanovic M, Sharpe F. Soft-tissue coverage of the elbow. Plast Reconstr Surg 2013;132(3):387e-402e [PubMed: 23584626]

3 Levin LS. The reconstructive ladder. An orthoplastic approach. Orthop Clin North Am 1993;24(3):393-409 [PubMed: 8101984]

4 Farber GL, Taylor KF, Smith AC. Pedicled thoracoabdominal flap coverage about the elbow in traumatic war injuries. Hand (N Y) 2010;5(1):43-48
5 Pierce TD, Tomaino MM. Use of the pedicled latissimus muscle flap for upper-extremity reconstruction. J Am Acad Orthop Surg 2000;8(5):324-331

6 Longo UG, Franceschi F, Loppini M, Maffulli N, Denaro V. Rating systems for evaluation of the elbow. $\mathrm{Br}$ Med Bull 2008;87(1):131-161

7 Lister G, Scheker L. Emergency free flaps to the upper extremity. J Hand Surg Am 1988;13(1):22-28

8 Ninkovic M, Deetjen H, Ohler K, Anderl H. Emergency free tissue transfer for severe upper extremity injuries. J Hand Surg [Br] 1995;20(1):53-58

9 Hallock GG. The utility of both muscle and fascia flaps in severe upper extremity trauma. J Trauma 2002;53(1):61-65

10 Harvey EJ, Aponte R, Levin LS. Application of the island pedicle latissimus dorsi flap for soft tissue coverage of the elbow. Can J Plast Surg 1999;7(1):23-26

$11 \mathrm{Ma} \mathrm{CH}$, Tu YK, Wu CH, Yen CY, Yu SW, Kao FC. Reconstruction of upper extremity large soft-tissue defects using pedicled latissimus dorsi muscle flaps-technique illustration and clinical outcomes. Injury 2008;39(Suppl 4):67-74

12 Hacquebord JH, Hanel DP, Friedrich JB. The pedicled latissimus dorsi flap provides effective coverage for large and complex soft tissue injuries around the elbow. Hand (N Y) 2018;13(5):586-592

13 Stevanovic M, Sharpe F, Thommen VD, Itamura JM, Schnall SB. Latissimus dorsi pedicle flap for coverage of soft tissue defects about the elbow. J Shoulder Elbow Surg 1999;8(6):634-643

14 Jutte DL, Rees R, Nanney L, Bueno R, Lynch JB. Latissimus dorsi flap: a valuable resource in lower arm reconstruction. South Med J 1987;80(1):37-40

15 Derderian CA, Olivier WA, Baux G, Levine J, Gurtner GC. Microvascular free-tissue transfer for traumatic defects of the upper extremity: a 25-year experience. J Reconstr Microsurg 2003;19(7):455-462

16 Chen HC, Tang YB, Mardini S, Tsai BW. Reconstruction of the hand and upper limb with free flaps based on musculocutaneous perforators. Microsurgery 2004;24(4):270-280

17 Wang HT, Fletcher JW, Erdmann D, Levin LS. Use of the anterolateral thigh free flap for upper-extremity reconstruction. J Hand Surg Am 2005;30(4):859-864

18 Choudry UH, Moran SL, Li S, Khan S. Soft-tissue coverage of the elbow: an outcome analysis and reconstructive algorithm. Plast Reconstr Surg 2007;119(6):1852-1857

19 Chui $\mathrm{CH}$, Wong $\mathrm{CH}$, Chew WY, Low MH, Tan BK. Use of the fix and flap approach to complex open elbow injury: the role of the free anterolateral thigh flap. Arch Plast Surg 2012;39(2):130-136

20 Morrey BF, Askew LJ, Chao EY. A biomechanical study of normal functional elbow motion. J Bone Joint Surg Am 1981;63(6):872-877

21 Spindler N, Al-Benna S, Ring A, et al. Free anterolateral thigh flaps for upper extremity soft tissue reconstruction. GMS Interdiscip Plast Reconstr Surg DGPW 2015;4:1-8 10.3205/ iprs000064, ISSN 2193-8091 